\title{
Trust in the media across Europe
}

\author{
Lars Nyre ${ }^{1}$ \\ Department of Information Science and Media Studies \\ University of Bergen, Norway \\ Liina Puustinen ${ }^{2}$ \\ Department of Political and Economic Studies \\ University of Helsinki, Finland
}

\section{doi:10.5937/comman1326007N}

This special issue on audiences' trust in the media comes out of the COST action "Transforming Audiences, Transforming Societies" (2010-2013). The first versions of many of the papers were presented at a panel about Trust in media at the action's first conference New challenges and methodological innovations in European media audience research, held at the University of Zagreb in April 2011. The idea of a special issue was taken further at the COST action's conference in London in 2011, and to widen the scope of contributors a call for papers was issued in the spring of 2012.

At present there is a flourishing interest in trust research, and the authors of this issue also relate to the special issue of the European Journal of Communication in 2012, where media scholars and sociologists discuss theoretical notions of trust. Our special issue is, however, more directly focussed on empirical research. In all, the articles are sociological by nature. They try to explain the invisible bond that makes humans trust each other to act in the interest of the other, and they look for patterns and rules for how humans relate to each other through institutions. This is a major theme in modern sociology, and the authors draw on a theoretical tradition where Anthony Giddens, Niklas Luhmann, Piotr Sztompka and Russel Hardin are central contributors.

\footnotetext{
${ }^{1}$ lars.nyre@infomedia.uib.no

2 liina.puustinen@helsinki.fi
} 
Trust research traditionally has two theoretical and empirical foci; trust in institutions and trust in persons. The issue begins with analyses of the hermeneutic, qualitative, personal dimensions of trust, but overall it is dominated by explorations of generalized trust in institutions. Our menu spans five different European countries, all dealing with contemporary times, from circa 2000 to the present.

Audience experience is at the core of our interests. This is where trust is performed, so to speak. The first article is a careful empirical analysis of the quite ordinary act of looking at war photographs in newspapers. "The image of trust. Readers' views on the trustworthiness of news photographs" is written by Liina Puustinen and Janne Seppänen from Finland. They ask whether Finns still trust news photographs in an era of digital manipulation. They find that people are able to be quite precise in their formulation of trust relations, and categorize them in four types; tacit trust, measured trust, contextual trust and doubt. All of these positions are relatively meta-reflective, and imply a finding that people are able to think for themselves.

The second article continues and expands the hermeneutical focus. "Trust in the imagined author. Identity, expertise and reputation" is written by Tereza Pavlícková, who works in the Czech Republic and the United Kingdom. She presents a sharp empirical analysis of the way the internet has confused the identity of authors. Using qualitative interviews with young adults she argues that trust is shaped by perception of the author's identity, expertise and reputation.

The formation of trust relations in contemporary Europe is necessarily influenced by social media. These interactive, non-editorial media help to change the power relations between media and audiences, as they add to the already high media-diversity and multi-platform behaviour. Social media are not only a good thing, and this issue is addressed head on in the third article. "Social networking sites are untrustworthy news sources" is written by Jelena Jurišić and Ivana Šipić from Croatia. In this normative text they claim that journalists are poor at understanding social media, and that the quality of journalism suffers. The critique is most poignant for Croatia, but to varying degrees appropriate also for other European countries.

There seems to be a lack of institutional frameworks for the new media, and the growth of new institutional solutions may threaten traditional or 'legacy media'. This brings us to the fourth article, which is "Trust in the diverging, 
convergent multi-platform media environment" by Guy Starkey in England. Monopoly is a thing of the past, and now there may be several dozen channels in any home in any European country. People have to develop skills in media literacy in order to tackle this bewildering diversity. Starkey argues that trust was once placed hegemonically in state monopolies and public/private duopolies, but with diversity and fragmentation it is placed in the strongest brands; the ones that remain most visible in the everyday situation of the audiences.

With the fifth article, the method changes. The three last articles do statistical analyses of generalized trust, especially related to state institutions and marked-driven media. In their article "Trust in the context of audience fragmentation" Ragne Kóuts, Peeter Vihalemm and Marju Lauristin from Estonia, continue the exploration of fragmentation and lack of institutional frameworks that Pavlíčková, and Jurišić and Šipić also pursue. They present a study on the many-faceted influences on audiences' trust on a national level for Estonia. The authors identify several types of users, where the dominant is the "multi-active" user $(23 \%)$, who not only are heavy users of all media channels, but also the most trustful in both media and state institutions. But at the same time they are extremely critical towards Estonian media performance, because they judge their own country in an international perspective. This type of audience is likely to be prevalent in may other countries too.

Statistics tells us that in many countries trust in media is positively correlated with trust in state institutions. The sixth article is called "Comparing the incomparable: Trust in media and state institutions", and is written by Gintaras Aleknonis from Lithuania. He explores the relationship between media and state institutions using data from the Eurobarometer; the large database of surveys dating decades back for EU countries. He argues that in experienced democracies trust primarily rests in democratic state institutions, while trust in media is secondary. However, countries with fresh memory of a totalitarian past live in a transitional period where the role of state institutions and marketdriven media are more equal.

The concept of 'institution' is important in trust research, and in our seventh and final article it is studied in careful theoretical and empirical detail: "Institutional trust in the Croatian post-socialist context", written by Antonija Čuvalo from Croatia. Čuvalo confirms Aleknonis' argument about the difference between established democracies and transitional countries. She shows that political trust in Croatia is still, after two decades of transition, not inde- 
pendent from trust in media. Measured in relation to trust, the media have a more prominent role in Eastern Europe than in the west.

With this menu of empirical contributions we believe we have added to the growing literature on trust, and the European focus on it. Special thanks to Kim Schröder, the head of the "Working Group 1: New Media Genres, Media Literacy, and Trust in the Media" of the COST action, Jelena Kleut of the CMQ, proof-reader Jane Corrigan and the reviewers, who must remain anonymous. 